\title{
Phytoremediation of Contaminated Soils-A Review
}

\section{S. R. Shrirangasami ${ }^{1}$, S. S. Rakesh ${ }^{2,}$ R. Murugaragavan ${ }^{2 *}$, P. T. Ramesh $^{3}$, S. Varadharaj ${ }^{4}$, R. Elangovan ${ }^{5}$ and S. Saravanakumar ${ }^{6}$}

${ }^{1}$ Rice Research Station, Tamil Nadu Agricultural University, Ambasamudram, Tamil Nadu, India

${ }^{2}$ Department of Environmental Sciences, AC\&RI, TNAU, Coimbatore, Tamil Nadu, India

${ }^{3}$ Department of Soils Science and Agricultural Chemistry, Agricultural College and Research

Institute, Tamil Nadu Agricultural University, Killikulam, Tamil Nadu, India

${ }^{4}$ Department of Social Science, Horticultural College and Research Institute, Tamil Nadu

Agricultural University, Periyakulam, Tamil Nadu, India

${ }^{5}$ College of Agricultural Technology, Tamil Nadu Agricultural University, Theni,

Tamil Nadu, India

${ }^{6}$ National Remote Sensing Centre, Hyderabad, Telungana, India

\section{*Corresponding author}

\section{A B S T R A C T}

\section{Keywords}

Phytoremediation, Rhizoremediation, Xenobiotics, Pesticides

\section{Article Info}

Accepted:

22 October 2020

Available Online:

10 November 2020

Phytoremediation includes phytotransformation (transformation of organic contaminants into a less toxic, less mobile, or more stable form), phytodegradation (metabolism of the organic contaminant by the plant enzymes), phytovolatilization (volatilization of organic contaminants through plant leaves), and rhizoremediation. At the soil root interface (rhizosphere), plant roots exude organic compounds that support a large and active microcosm, which leads to higher biodegradation of toxicants in the rhizosphere ecosystem. The mechanisms adopted by plants, microorganisms, and algae to interact with various types of pollutants. Phytoremediation is a cost effective and novel technology that uses plants to clean up a wider range of organic and inorganic toxicants. Plants can bioaccumulate the xenobiotics in their above ground parts, which are then harvested for removal.

\section{Introduction}

The native flora which was found in the polluted sites were efficient in removing pollutants especially metals, metalloids, pesticide residues etc., There are seven main methods and mechanisms adopted by plants, microorganisms, and algae to cope with various types of pollutants. These include (1) Rhizosphere biodegradation, (2) Phytostabilization, (3) Phyto-accumulation (Phytoextraction), (4) Rhizo-filtration, (5) Phyto volatilization, (6) Phyto-degradation (Phytotransformation), and (7) Hydraulic control. 
Phyto-extraction or phyto-accumulation, in which plants absorb elements from the contaminated soil and accumulate them in various plant organs. This mechanism is often referred to as phytomining; where the plant tissues are considered mines, and harvesting of elements from plant tissues is deemed mining; (2) Phyto-stabilization, in which metals are immobilized (e.g., by adsorption and precipitation). To achieve this, plant roots release substances into the soil; these include organic matter, phosphates, and alkalizing agents. Unless properly disposed of, metals accumulated in plant tissues might negatively impact the environment and human life (e.g., via the food chain).

\section{Pesticides}

"Pesticides" is the collective term for all chemicals that are used to counteract a certain group of organisms. The primary classes of pesticides are insecticides (against insects), herbicides (against plants) and fungicides (against fungi). However, inside these different classes, there still is a wide variety between the compounds and their chemical properties. They are defined by their ionic or nonionic properties, hydrophobic properties, mechanism of action and their molecular structure (Gavrilescu, 2005). Pesticides not only cause many chronic abnormalities in human beings but may also degrade biodiversity and overall environmental quality (Benachour et al., 2007). Phytoremediation encompasses many processes, such as phytotransformation (transformation of organic contaminants into a less toxic, less mobile, or more stable form), phytodegradation (metabolism of the organic contaminant by the plant enzymes), phytovolatilization (volatilization of organic contaminants through plant leaves), and rhizoremediation. At the soil-root interface (rhizosphere), plant roots exude organic compounds that support a large and active microbial population, which leads to enhanced biodegradation of contaminants in the rhizosphere.

Phytoremediation is also a cost-effective and innovative technology that uses plants to clean up a broad range of organic and inorganic wastes (Licht and Isebrands, 2005). Plants can bioaccumulate xenobiotics in their above-ground parts, which are then harvested for removal. Plants may contribute to remediation in several ways, by reducing the leaching of contaminants, aerating soil, phytodegradation/ transformation, phytovolatilization, evapotranspiration, and rhizoremediation (Chang et al., 2005). Recently, molecular breeding of transgenic plants expressing enzymes responsible for phytoremediation of pesticides has begun to gain interest in the scientific community (Bode et al., 2006; Chrastilova et al., 2007; Novakova et al., 2007).

The four main groups of insecticides are: organochlorines, organophosphates, carbamate esters and pyrethroids. When considering insecticide contamination, organochlorines are often the chemicals of greatest concern. Commonly known members of this group are the DDT (dichlorodiphenyltrichloroethane), DDE (dichlorodiphenyldichloroethylene), DDD (dichlorodiphenyldichloroethane), the HCHs (hexacyclochlorohexanes: a, b, g, d, t) and chlordane (Pascal Lorber and Laurent, 2011). The behaviour of pesticides in the environment is influenced by a combination of natural processes. When in the environment, pesticides interact with soils, water and organisms and the interactions are controlled by a complex collection of biological, physical and chemical reactions

The most widespread herbicide contamination occurs with atrazine (Pascal Lorber \& Laurent, 2011). Atrazine (2-chloro-4(aminoethyl) -6- (aminoisopropyl)-s-1,3,5- 
triazine) is a photosynthesis-inhibiting herbicide and is used in agriculture for the control of annual grasses and broad-leaved weeds, as well as in industrial sites and along railroads (Garmouna et al., 1998). This caused widespread contamination of surface and groundwater reservoirs. Atrazine is known to be an endocrine disruptor, and significant toxicity has been noted in amphibians (Forson and Storfer, 2006).

DDTs strongly adsorb to soil particles, further enhanced by alternate drying and wetting. Due to their hydrophobic and lipophilic nature, DDTs naturally accumulate in adipose tissue and often get magnified in the food chain. Several higher trophic level animals have been shown to experience deleterious effects of DDT exposure, e.g., egg shell thinning in birds and endocrine disruptors in mammals (Sharpe, 1995). The most important contaminants are hexachlorobenzene (HCB) and pentachlorophenol. HCB is a hydrophobic organic compound that is known for its bioaccumulation and the analyte has been detected in air, soil, fish, birds and even human milk (Qiu et al., 2004).

The processes that influence pesticide contamination can be classified into three types: (1) transport processes, which move the pesticide from the original point of introduction, (2) transfer processes that control the pesticides movement through environmental compartments such as water, sediments, the atmosphere and biota and (3) transformation processes that change the structure/nature of a pesticide or even completely degrade it to its constituent elements.

Pesticide transformation or degradation is the oxidation of pesticide molecules. When a pesticide is introduced into the environment, it is prone to different transformation pathways. First, there is a chemical degradation, where the analytes react with organisms or enzymes in the environment and degradation occurs. Secondly, the molecules can be degraded by exposure to light; photodegradation. Thirdly, microbial degradation can occur in both bulk and rhizosphere soil.

Phytoremediation is also to be considered to be an innovative, cost-effective and ecologically beneficial technology (Hussain et al., 2009). Phytoremediation is a collection of processes, including phytotransformation, phytodegradation, phytovolatilization and rhizoremediation. For the first three processes, uptake of the contaminant into the plant tissues is necessary; rhizoremediation takes place at the soil-root interface or rhizosphere. All of the above-mentioned phytoremediation processes can be influenced by plant-associated microorganisms. Both rhizospheric and endophytic microorganisms can play a role in the remediation through pesticide degrading and plant growth promoting capacities (Glick, 2003).

The degradation of pesticides is often greater in rhizosphere soil than it is in bulk soil. This can be explained by a phenomenon known as the rhizosphere effect. The presence of microbial communities in the soil can be beneficial to the plant by producing protective or beneficial compounds such as 1aminocyclopropane-1-carboxylate (ACC) deaminase. ACC is the precursor molecule for ethylene, which is a stress hormone that plants often produce in contaminated soils. ACC deaminase degrades ACC, ethylene levels are lowered and the plants experience less stress from contaminant exposure. All of these mechanisms can decrease plant phytotoxicity, increase plant growth and increase phytoremediation potential.

Plant root systems can excrete enzymes that degrade pesticides in the rhizosphere, but they 
also release photosynthetic products that can serve as nutrients for rhizospheric bacteria. Kidd, Prieto-Fern_andez, Monterroso, and Acea (2008) showed a higher dissipation of $\mathrm{HCHs}$ in the rhizosphere when Cytisus striatus and Holcus lanatus were inoculated with $\mathrm{HCH}$ degrading bacteria. Ahmad et al., (2012) reported a 50\% increase in chlorpyrifos degradation in the Lolium multiflorum rhizosphere when the plant roots were inoculated with Bacillus pumilus C2A1. The successful degradation of phoxim when carrot (Daucus carota) and green onion (Allium fistulosum) were inoculated with the arbuscular mycorrhizal fungi Glomus intraradices and Glomus mosseae; notably, contaminant degradation was negligible in noninoculated plants. The fungus Trichoderma harzianum was isolated from a marine plant Didemnum ligulum and had the capacity to degrade $50 \mathrm{mg} / \mathrm{L}$ phoxim in liquid medium in 7 days (Vacondio et al., 2015). The scientists conducted a large experiment on pesticide degradation by fungi. These researchers tested 17 white rot fungi; 16 were able to degrade the pesticides parathion, terbufos, azinphos-methyl, phosmet and tribufos after a four day growth period.

Phillips et al., (2006) reviewed the degradation of $\mathrm{HCH}$ in soil and reported many research findings that showed a degradation of $\mathrm{HCH}$ isomers under anoxic environment. Temperature and $\mathrm{pH}$ are the major factors affecting the biodegradation of pesticides in soil (Arshad et al., 2007). Temperature not only affects the rates of biochemical reactions, as all microbial activities depend on thermodynamics, but also has a direct impact on cell physiology-altering proteins and cell membrane permeability. A temperature range of 15 to $40{ }^{\circ} \mathrm{C}$ was considered favorable for the degradation of pesticides by isolated pesticide-degrading bacteria.
In soil, the main source of organic matter that provides nutrients is crop residues. The application of wheat residue-derived char released nutrients and stimulated microbial growth and degradation of pesticide (benzonitrile) in soil. Phosphorus was primarily responsible for stimulation and degradation. Slow degradation of benzonitrile after its $88 \%$ degradation was attributed to adsorption on char. Organic matter characteristics (i.e., aromaticity) can vary among the organic fractions and may lead to differences in sorption capacity (Ding et al., 2002). Also, different groups of pesticides behave differently in soils. Boivin et al., (2005) correlated adsorption of non-acidic pesticides (atrazine, isoproturon, and trifluralin) to soil organic matter content. Singh et al., (2006) studied the biodegradation of organophosphate pesticides (fenamifos and chlorpyrifos) and did not find any impact of soil organic matter on the pesticide biodegradation rates. In another study, Fenlon et al., (2007) found that diazinon (organophosphate pesticide) only appreciably mineralized in two of the organic soils when assessed in organically and conventially managed soils compared to cypermethrin (pyrethroid), which degraded significantly in all the investigated soils. This contrasts with earlier reports where high organic matter reduced biodegradation by reducing the bioavailability of compounds to degrading microorganisms, especially when the compounds have high Koc value (Karpouzas et al., 2000).

The uptake of pesticides by plants is governed by numerous soil and plant characteristics. Soil factors that influence the availability of pesticides in soil for either microbial degradation or plant uptake. In addition to moisture content, organic carbon, and clay content in soil, pesticide residence time in the soil can also affect its availability for transport and plant uptake. Sorption 
desorption of two sulfonylaminocarbonyltriazolinone herbicides in clay loam and loamy sand soils. In both soils, 12 weeks of incubations increased sorption $(K d)$ by a factor of 5 to 7 . The uptake of pesticides varies among different plants. The uptake of pesticides (atrazine and lambda-cyhalothrin) from water by two different plants (Juncus effusus and Ludwigia peploides) under hydroponic conditions. Higher atrazine uptake was measured in J. effuses, and higher lambda-cyhalothrin uptake occurred in $L$. peploides. Atrazine was translocated to upper plant biomass in macrophytes, while $98.2 \%$ of lambda-cyhalothrin was sequested in roots of L. peploides, of which $25.4 \%$ was translocated to upper plant biomass. The removal of pesticides from soil by plants also relies on pesticide type. The tendency of a pesticide to partition from water into organic phase (Kow) controls its bioavailability and translocation in plant (Bromilow \& Chamberlain, 1995). Twelve non-ionized pesticides with different physicochemical properties were studied by Carvalho et al., (2007). The uptake of pesticides by roots and shoots of an aquatic plant, parrot feather (Myriophyllum aquaticum). Root concentration factor (RCF) and submerged shoot concentration factor (SSCF) increased with increasing Kow of the pesticide. In an uptake study of hydrophobic organochlorine pesticides (OCPs) in vegetables, Gonzalez et al., (2005) observed that vegetables accumulated OCPs efficiently with tissue residues 4- to 45-fold greater than those of soils, and OCP distribution in tissue was found to be Kow-dependent.

Apart from soil and pesticide properties, pesticides undergo chemical or biological transformations in water and soil environments and form metabolites, which are often weak electrolytes and may be readily taken up by plants (Trapp, 2000). In an environment contaminated with multifarious pollutants, the presence of heavy metals can affect the uptake of pesticides by plants. Su et al., (2005) revealed that the interaction between cadmium $\left(\mathrm{Cd}^{2+}\right)$ and atrazine reduced the individual toxicities to rice seedlings. The addition of equimolar concentrations of $\mathrm{Cd}^{2+}$ and atrazine in a solution increased the bioconcentration factor (BCF) of atrazine in roots and shoots of rice seedlings. Though soil-to-plant is a major route of pesticides uptake, plants can also absorb airborne pesticides. Lee et al., (2003) conducted a study using the insecticide chlordane and reported significantly different compositional profiles of chlordane components in zucchini (Cucurbita pepo L.) plant tissues exposed to airborne and soil chlordane in parallel studies, which suggested two distinct plant uptake routes for the insecticide. Grangeot et al., (2006) studied the spray retention, foliar uptake, and translocation of glufosinate and glyphosate in Ambrosia artemisiifolia. Their results indicated that glufosinate was readily taken up (maximum; >80\% of the applied label) by A. artemisiifolia leaves, with half of the maximum uptake being reached within $6 \mathrm{~h}$. The foliar uptake of glyphosate was nearly complete, and half of it was attained in $3 \mathrm{~h}$. Glufosinate and glyphosate were ambimobile, and their translocation out of the treated leaves amounted to $13-16 \%$ and $11-15 \%$, respectively, of the absorbed radioactivity. After uptake, glufosinate was mainly distributed in the apical developing tissues, while glyphosate was distributed in apical developing tissues as well as roots.

Xia and Ma (2006) revealed that water hyacinth (Eichhonia crassipes) removed ethion, an organophosphorus insecticide, from water and degraded the pesticide within the plant. Similarly, poplar cuttings could take up atrazine and hydrolyze and dealkylate it to less toxic metabolites in roots, stems, and leaves (Chang et al., 2005). In another study, 
dehalogenation of DDT was observed in aquatic plant elodea (Elodea canadensis) (Garrison et al., 2000). The primary transformation reactions (phase I) within plants are catalyzed by induced endogenous enzymes that attack common functional groups of pesticides like $\mathrm{NO}_{2}^{-}, \mathrm{NH}_{2}^{-}, \mathrm{OH}^{-}$, $\mathrm{COOH}^{-}$or $\mathrm{Cl}^{-}, \mathrm{Br}^{-}$, and $\mathrm{I}^{-}$by oxidation, reduction, or hydrolysis reactions. Conjugation takes place by the addition of a sugar moiety or tripeptide like glutathione to the contaminant or a newly transformed product. In most cases, glutathione (GSH) forms conjugates with various xenobiotics such as pesticides by nucleophilic addition reactions catalyzed by glutathione- $S$ transferase (GST) (Edwards et al., 2000). The expression of GST encoding genes is induced by many xenobiotics such as pesticides. pesticides that undergo conjugation with glutathione are atrazine, simazine, and cyanazine, while 2,4-D, chloramben, and bentazon prefer conjugation with glucose. Conjugates formed by either method are less toxic due to having more water solubility than the parent compound and are sequestered into the vacuole where they can be further degraded (Edwards et al., 2000; Foyer \& Noctor, 2001). Conjugated compounds require adenosine triphosphate (ATP)dependent enzymes to move into the vacuole, and their transport across the vacuole has been demonstrated in many plant species. Enzymes that catalyze the entry of glutathione and glycosyl-derivatives are glutathione and glucoside-conjugate transporters, respectively. ATP-binding cassette (ABC) transporters are the best-characterized system for transferring pesticides out of root cells and into vacuoles after conjugation by GSTs. During metabolic processes, insoluble conjugates with cell wall components are also formed in plants either by nonselective reactions with free radicals used in lignin synthesis or by more selective incorporation into hemicelluloses. In phase III, plant metabolism is confined to compartmentation and storage. Unlike mammals, plants do not possess a way to excrete unwanted compounds. Soluble metabolites are stored in the vacuole or become part of cell wall material. Davis and Erickson (2002) reviewed the potential for volatization of fumigants ethylene dibromide, ethylene dichloride, and carbon tetrachloride. Field studies in Florida and Utah revealed trichloroethylene (TCE) uptake by all exposed plants at both sites, but TCE concentration in plant was 10-100 times higher at the Utah site. TCE could only be identified in transpiration samples collected at the Utah site. The lack of phytovolatilization and significantly lower TCE plant concentrations at the Florida site were most likely due to the smaller fraction of contaminated groundwater used by plants for transpiration because of the frequent precipitation (Doucette et al., 2003).

The term rhizosphere describes the soil volume around plant roots, which is influenced by the activities of the living roots. Rhizosphere is a complex environment that supports a huge number of metabolically active microbial populations, several orders of magnitude higher than the non-rhizospheric soil (Capdevila et al., 2004). Rhizoremediation significantly depends upon the type of relevant gene pool in the rhizosphere for a particular pesticide. Moreover, exchanges in genetic makeup of rhizosphere caused by foreign gene in terms of horizontal gene transfer among microbial communities may be helpful to maximizing the rhizodegradation of pesticides. Studies have described the horizontal gene transfer of degradative genes from foreign bacteria to indegeneuos soil bacteria, which may enable indegeneuos soil microorganisms to degrade pesticides in the soil environment. The horizontal transfer of organophosphorus pesticide hydrolase gene cluster and methylcarbamate degrading $m c d$ gene (Desait 
et al., 2003) in microbial populations in soil. de Lipthay et al., (2001) showed that horizontal transfer of 2,4dichlorophenoxyacetic acid/2-oxoglutarate dioxygenase encoding gene tfdA to phenoldegrading strains significantly enhanced the degradation rate of phenoxyacetic acid in sterile and non-sterile soil microcosms. These results strongly acknowledge that inoculation of plants with microbes containing catabolic plasmid could be helpful in their dissemination among microbial species to degrade xenobiotic compounds in the rhizosphere. Bacterial diversities belonged to actinobacteria, bacteroidetes, and proteobacteria. The major dominant families were highly similar to Variovorax paradoxus, Burkholderia cepacia, Arthrobacter sp., and Bosea sp. Though various atrazine-degrading gene compositions were observed, two of these are $a t z \mathrm{ABCDEF}, t r z \mathrm{ND}$ and $a t z \mathrm{BCDEF}$, $\operatorname{tr} z \mathrm{~N}$ were largely dominant. The first was dominant in bacterial communities isolated from the maize rhizosphere, while the second was dominant in bacterial communities isolated from bulk soil. According to the results obtained, maize rhizosphere imparted a significant impact on the genetic structure, diversity, and pesticides degrading gene composition.

Sonoki et al., (2005) introduced an extracellular fungal enzyme, the laccase of Coriolus versicolor, into tobacco plants. The transgenic plant was able to remove pentachlorophenol by producing laccase and secreting into the rhizosphere. Similarly, for the decontamination of organophosphorus pesticide, Wang et al., (2008) expressed a bacterial organophosphorus hydrolase $(\mathrm{OPH})$ gene in tobacco plants. The transgenic plants degraded more than $99 \%$ of methylparathion after 14 days of growth. A variety of plant enzymes, including peroxygenases, cytochrome P450, peroxidase, glutathione- $S$ transferases, carboxylesterases, $\quad \mathrm{N}$-, Oglucosyltransferases and $N-, \quad O-$ malonyltransferases, are involved in the phytotransformation of xenobiotics in plant cells (Wolfe and Hoehamer, 2003). Glutathione $S$-transferases are a multigene family of detoxifying enzymes for herbicides. The gene gstI-6His from maize, which encodes for 6His-tagged GST I, was used for the construction of a binary vector suitable for genetic engineering of tobacco plants (Nicotiana tabacum).

Peuke and Rennenberg (2005b) used transgenic poplars with enhanced GSH synthesis in a greenhouse experiments and revealed that transgenic poplars showed a high potential for uptake and detoxification of heavy metals and pesticides. GSH is synthesized in two ATP-dependent steps catalyzed by $\alpha$ - glutamylcysteine synthetase $(\gamma$-ECS) and glutathione synthetase (GSHS). Shiota et al., (1994) first reported the enhanced resistance of transgenic tobacco (Nicotiana tabacum cv. Xanthi) plants toward herbicide chlortoluron, expressing a genetically engineered fused enzyme between rat cytochrome P4501A1 (CYP1A1) and yeast NADPH-cytochrome P450 oxidoreductase. In these plants, microsomal monooxygenase activities were approximately 10 times higher toward both 7ethoxycoumarin and benzopyrene than in the control plant (non-transgenic plants). Shiota et al., (1996) reported that transgenic tobacco plants expressing the genetically engineered fused enzyme between rat cytochrome P4501Al and yeast NADPH-cytochrome P450 oxidoreductase were resistant to chlortoluron at concentrations of 10 to $50 \mu \mathrm{M}$ in Murashige and Skoog medium, but herbicide concentration up to $10 \mu \mathrm{M}$ was toxic to control plants. Inui et al., (2001) investigated the metabolism of 50 herbicides and 7 other chemicals with different structures and modes of action in the microcosms by recombinant yeast strains expressing each of 11 human P450 species. Of these, 27 herbicides and 6 other chemicals 
were mainly metabolized by CYPIAl, CYP1A2, CYP2B6, CYP2C9, CYP2C18, CYP2C19, CYP2D6, and CYP3A4 genes. Afterward, on the basis of these results, they developed transgenic potato plants T1977 expressing and co-expressing three major P450 species CYP1A1, CYP2B6, and CYP2C19. These plants exhibited crosstolerance toward the herbicides acetochlor, atrazine, chlortoluron, methabenzthiazuron, metolachlor, norflurazon, and pyributicarb, and demonstrated a higher activity in the metabolism of each of chlortoluron, atrazine, pyributicarb, and methoxychlor than nontransgenic control plants.

Yamada et al., (2002a, 2002b) first integrated a rat cytochrome $\mathrm{P} 450$ gene (CYP1A1) under the control of patatin promoter into potato to enhance tuber-specific expression. They developed a total of 106 transgenic plants PAT1A1 that demonstrated higher activity of monooxgenase in the leaves than the nontransgenic plants, when treated with $10 \%$ exogenous sucrose due to the patatin promoter containing the sucrose-inducted elements. Then, they selected one representative plant $(\mathrm{Ag} 2197)$ on the basis of monooxgenase activity in the leaves. The amount of residual herbicides was much less in Ag2197 plants than non-transgenic plant. Kawahigashi et al., (2003) introduced a human cytochrome P450 gene, CYP1A1, into rice plants (Oryza sativa $c v$. Nipponbare) to induce herbicide tolerance in rice plants

\section{Heavy metals}

Heavy metals are a group of 53 elements with density higher than $5 \mathrm{~g} / \mathrm{cm}^{3}$ Although some metals are essential for plant and animals, many are toxic at high concentrations. Trace elements like iron $(\mathrm{Fe})$, copper $(\mathrm{Cu})$, nickel $(\mathrm{Ni})$, zinc $(\mathrm{Zn})$, and manganese $(\mathrm{Mn})$ are essential for normal growth and development of plants and are required in electron transfer, in numerous enzyme catalyzed or redox reactions, and have structural function in nucleic acids. Others like $\mathrm{Cu}$ and $\mathrm{Zn}$ are involved in plant growth, flowering, and seed production, especially when their availability is very low (Vamerali et al., 2010).

In European Union, contamination by metals accounts for $>37 \%$ of the cases, followed by mineral oil (33.7\%), polycyclic aromatic hydrocarbons (13.3\%), and others (Vamerali et al., 2010). In uncontaminated soils, heavy metal concentrations vary in magnitudes, but on average, the order of metal concentrations is: $\mathrm{Cd} 0.1-0.5 \mathrm{ppm}, \mathrm{Zn} 80 \mathrm{ppm}$, and $\mathrm{Pb} 15$ ppm. However, in polluted soil, the concentrations were: $\mathrm{Cd}>14,000 \mathrm{ppm}, \mathrm{Zn}$ $>20,000 \mathrm{ppm}$, and $\mathrm{Pb}>7,000 \mathrm{ppm}$ (Gohre and Paszkowski 2006). Contamination is often highly localized in industrialized countries, and hence, the pressure to use contaminated land and water for food production or for human consumption is minimal. According to their distinct chemical and physical properties, three different molecular mechanisms of heavy metal toxicity are recognized: (1) production of reactive oxygen species by autoxidation and Fenton reaction $(\mathrm{Fe}, \mathrm{Cu}),(2)$ blocking of essential functional groups in biomolecules $(\mathrm{Cd}, \mathrm{Hg})$, and (3) displacement of essential metal ions from biomolecules (Schutzendubel and Polle 2002). Phytotoxicity is mainly associated with nonessential metals like $\mathrm{Cd}$, As, $\mathrm{Cr}$, and $\mathrm{Pb}$, which generally have very low toxicity thresholds and lower values for hyperaccumulation (especially for $\mathrm{Cd}$ ) than the other metals (Vamerali et al., 2010). At elevated concentrations, heavy metals interfere with essential enzymatic activities by modifying protein structure or by replacing a vital element resulting in deficiency symptoms. Phytostabilization and phytoextraction are the most reliable categories of phytoremediation for heavy metals (Gohre and Paszkowski, 2006). 
Phytostabilization is used to provide a cover of vegetation for a moderately to heavily contaminated site to prevent wind and water erosion. It is often performed using species from plant communities growing on local contaminated sites. These plants possess tolerance to the contaminant metals, develop an extensive root system, provide good soil cover, and ideally immobilize the contaminants in the rhizosphere. Plants most suitable for phytoextraction are able to hyperaccumulate contaminants, possess tolerance to these chemicals, have a high biomass, and have a short growing cycle (Cho et al., 2009).

Weissenhorn et al., (1995a, b) observed high levels of mycorrhizal colonization in agricultural soils contaminated with metals originating from smelter and sludge amendments. In ultramafic soils in South Africa, naturally occurring $\mathrm{Ni}$ hyperaccumulating plants of the Asteraceae were heavily colonized by AM-fungi. Weissenhorn et al., (1995a) observed no correlation between AM abundance in maize (Zea mays) and the degree of metal $(\mathrm{Cd}, \mathrm{Ni}$, $\mathrm{Zn}, \mathrm{Cu}, \mathrm{Pb}$, and $\mathrm{Mn}$ ) pollution in a field trial. On the other hand, mycorrhizal colonization and growth of external hyphae were inhibited by sewage sludge-contaminated soil containing $\mathrm{Pb}, \mathrm{Zn}$, and $\mathrm{Cd}$ (Del Val et al., (1999). Tonin et al., (2001) found that Cdand Zn-polluted soil enhanced mycorrhizal diversity index of clover (Trifolium repens L.) roots. Similarly, Turnau et al., (1996) reported that metal-tolerant Oxalis acetosella L. plants colonizing acid forest soils treated with $\mathrm{Cd}, \mathrm{Zn}$, and $\mathrm{Pb}$ containing industrial dust showed higher AM colonization than non treated soils.

Trace elements (TE) such as $\mathrm{As}, \mathrm{Cu}, \mathrm{Cr}$, and $\mathrm{Zn}$ can be in excess in contaminated soils at wood preservation sites, especially when $\mathrm{Cu}$ based salts, i.e. $\mathrm{Cu}$ sulphate and chromate copper arsenate (CCA), have been long term used as preservatives against insects and fungi, which may result in soil phytotoxicity (Kumpiene et al., 2008). Among the feasible remediation options, phytostabilisation, singly and in combination with mineral and organic amendments (i.e. aided phytostabilisation), is a less invasive, low-cost phytotechnology able to restore (1) the physical and chemical properties of TE contaminated soils and (2) the cascade of biological processes and functions leading to remediated ecosystem services (Bolan et al., 2014; Kumpiene et al., 2008). Crude oil is rich in heavy metals such as $\mathrm{Cd}, \mathrm{Cr}, \mathrm{Cu}, \mathrm{Ni}, \mathrm{Pb}, \mathrm{V}, \mathrm{Zn}$, etc. (Wake, 2005), while other heavy metals are associated with crude gas ( $\mathrm{Hg}$ and $\mathrm{As}$ ).

In situ (phyto) stabilisation techniques aim at decreasing both the labile TE pool and providing nutrient supply, and simultaneously promoting other beneficial process such as water retention, by incorporating organic and mineral amendments (Hattab et al., 2014). These techniques are able to enhance one or several processes such as metal adsorption through increased surface charge, formation of organic and inorganic metal complexes, sorption on $\mathrm{Fe}, \mathrm{Mn}$, and $\mathrm{Al}$ oxides, and precipitation (Kumpiene et al., 2008).

Glomalin, an insoluble glycoprotein, is produced abundantly and released by AM fungi and plays a critical role in soil stability. Glomalin also binds to heavy metals in the soil and can be extracted from soil together with a significant amount of bound heavy metals. Gonzalez-Chavez et al., (2004) reported that up to $0.08 \mathrm{mg} \mathrm{Cd}, 4.3 \mathrm{mg} \mathrm{Cu}$, and $1.12 \mathrm{mg} \mathrm{Pb}$ per gram glomalin could be extracted from polluted soils that were inoculated with laboratory cultures of AMfungi. Moreover, glomalin from hyphae of an isolate of Gigaspora rosea sequestered up to $28 \mathrm{mg} \mathrm{Cu} \mathrm{g-1} \mathrm{in} \mathrm{vitro.} \mathrm{Similarly,} \mathrm{Bedini} \mathrm{et}$ al., (2010) reported that the amount of $\mathrm{Cu}, \mathrm{Ni}$, $\mathrm{Pb}$, and $\mathrm{Co}$ bound to glomalin was $2.3,0.83$, $0.24,0.24 \%$, respectively, of the total content 
of heavy metals. Fungal cell wall is made up of chitin that has an important metal-binding capacity. And therefore, this binding ability of chitin is likely to reduce the concentration of heavy metals in soil. Mycorrhizal fungi improve phytoextraction by making metals more available for uptake by plants. Improved phytoextraction following mycorrhization may be achieved by several mechanisms like (1) better plant growth and biomass production, (2) increased plant tolerance to metals, and (3) greater metal concentrations in plant tissues (Vamerali et al., 2010). Pteris vittata L. (Chinese brake fern) was the first reported of the eight As hyperaccumulator plant species identified so far. It has been found to accumulate As in its fronds with extraordinary efficiency, primarily due to high translocation from roots to shoots and to effective detoxification mechanisms within the plant. Low to moderate (4.2-12.8\%) levels of AM colonization have been observed in $P$. vittata growing at several Ascontaminated sites. The non-AM $P$. vittata plants accumulated $60.4 \mathrm{mg}$ As per $\mathrm{kg}$ while plants colonized by AM-fungi isolated from an As mine accumulated $88.1 \mathrm{~g}$ As per $\mathrm{kg}$ accompanied by enhanced growth. Phosphate uptake was $36.3 \mathrm{mg}$ per pot in non-colonized and $257 \mathrm{mg}$ per pot in colonized plants. AMfungi are likely to have a strong influence on arsenate uptake due to their role in enhancing phosphate acquisition for the host plants. Mycorrhizal hyphae and plants can modify plant uptake of As by means of changes in the biotransformation of $\mathrm{As}$ at the interface between roots and rhizosphere soil (Ultra et al., 2007), downregulation of arsenate or phosphate transporters in the epidermis and root hairs (Gonzalez-Chavez et al., 2002), retention of As in external mycelium and/or possibly increased efflux of As as arsenite from mycorrhizal roots (Wang et al., 2008), and alteration of the translocation of As from roots to shoots. Arbuscular mycorrhizal fungi can also induce the accumulation of other heavy in host roots. Berkheya coddii Roessler, a Ni-hyperaccumulator plant of family Asteraceae, for example is used for phytomining, that is, for the recovery of metals from plant tissues (Salt et al., 1998).

Among higher plants, poplars and perennial grasses possess a strong phytostabilisation capability (Marmiroli et al., 2011). The immobilization of TE in soil can also be induced through the use of soil amendments that reduce TE mobility and bioavailability (Hooda 2010). Several mineral and organic amendments such as lime, coal fly ashes, phosphates, red muds, compost, biosolids, iron grit and $\mathrm{Fe}$ or $\mathrm{Mn}$ or $\mathrm{Al}$ oxides can improve phytostabilisation and production of plant-based feedstock through decrease in TE bioavailability (Kumpiene et al., 2008). The arylamine $N$-acetyltransferases (NAT) are xenobiotic-metabolizing enzymes that catalyze the transfer of an acetyl group from acetyl CoA (AcCoA) to the nitrogen or oxygen atom of arylamine based xenobiotics and their hydroxylated metabolites. They play an important role in the detoxification of many xenobiotics and pesticides.

In conclusion this review paper provides wider conceptual as well as experimental methodologies for removing contaminants in the ecosystem by plants, microorganism, algae etc., due to increasing population and industrialization the entire world is contaminated with different types of pollution and its impact on environment is very serious that encounter immeasurable problems to living forms. To solve the problem by enhancing the green belt by afforestation or encourage the native plant species conservation to remove the toxicants in the environment.

\section{References}

Ahmad, F., Iqbal, S., Anwar, S., Afzal, M., Islam, E., Mustafa, T., \& Khan, Q. M. 
(2012). Enhanced remediation of chlorpyrifos from soil using ryegrass (Lollium multiflorum) and chlorpyrifos degrading bacterium Bacillus pumilus C2A1. Journal of Hazardous Materials. 237-238: 110-115.

Arshad, M., Hussain, S., \& Saleem, M. (2007). Optimization of environmental parameters for biodegradation of alpha and beta endosulfan in soil slurry by Pseudomonas aeruginosa. Journal of Applied Microbiology. 104:364-370.

Bedini S, Turrini A, Rigo C, Argese E, Giovannetti M (2010) Molecular characterization and glomalin production of arbuscular mycorrhizal fungi colonizing a heavy metal polluted ash disposal island, downtown Venice. Soil Biol Biochem. 42:758-765

Benachour, N., Moslemi, S., Sipahutar, H., and Seralini, G.E. (2007). Cytotoxic effects and aromatase inhibition by xenobiotic endocrine disrupters alone and in combination. Toxicol. Appl. Pharmacol., 222: 129-140.

Bode, M., Haas, M., Faymonville, T., Thiede, B., Schuphan, I., and Schmidt, B. (2006). Biotransformation of metamitron by human P450 expressed in transgenic tobacco cell cultures. $J$. Environ. Sci. Health. 41: 201-222.

Boivin, A., Cherrier, R., and. Schiavon, M. (2005). A comparison of five pesticides adsorption and desorption processes in thirteen contrasting field soils. Chemosphere. 61:668-676.

Bolan, N., Kunhikrishnan, A., Thangarajan, R., Kumpiene, J., Park, J., Makino, T., Kirkham, M.B. \& Scheckel, K. 2014. Remediation of heavy metal(loid)s contaminated soils - To mobilize or to immobilize? Journal of Hazardous Materials, 266: 141-166.

Bromilow, R.H., and Chamberlain, K. (1995). Principles governing uptake and transport of chemicals. In: Trapp, S., and
McFarlane, J.C. (eds.). Plant contamination: Modeling and simulation of organic chemical processes. Boca Raton, Fla., Lewis Publishers.

Capdevila, S., Mart'inez-Granero, F.M., S'anchez Contreras, M., Rivilla, R., and Martin M. (2004). Analysis of Pseudomonas fluorescens F113 genes implicated in flagellar filament synthesis and their role in competitive root colonization. Microbiol., 150: 3889-3897.

Carvalho, R.F.D., Bromilow, R.H., and Greenwood, R. (2007). Uptake of pesticides from water by curly waterweed Lagarosiphon major and lesser duckweed Lemna minor. Pest. Manag. Sci., 63: 789-797.

Chang, S.W., Lee, S.J., and Je, C.H. (2005). Phytoremediation of atrazine by poplar trees: Toxicity, uptake, and transformation. J. Environ. Sci. Health. 40: 801-811.

Cho Y, Bolick JA, Butcher DJ (2009) Phytoremediation of lead with green onions (Allium fistulosum) and uptake of arsenic compounds by moonlight ferns (Pteris cretica cv Mayii). Microchem J. 91:6-8

Chrastilova, Z., Mackova, M., Novakova, M., Macek, T., and Szekeres, M. (2007). Transgenic plants for effective phytoremediation of persistent toxic organic pollutants present in the environment. J. Biotechnol., 131: S38.

Davis, L.C., and Erickson, L.E. (2002). A review of the potential for phytovolatilization of the volatile contaminants ethylene dibromide, ethylene dichloride, and carbon tetrachloride. Proc. Conference on Application of Waste Remediation Technologies to Agricultural Contamination of Water Resources, July 30-August 1, Kansas City, Missouri, 
USA.

de Lipthay, J.R., Tuxen, N., Johnsen, K., Hansen, L.H., Albrechtsen, H.-J., Bjerg, P.L., and Aamand, J. (2003). In situ exposure to low herbicide concentrations affects microbial population composition and catabolic gene frequency in an aerobic shallow aquifer. Appl. Environ. Microbiol., 69: 461-467.

Del Val C, Barea JM, Azcon-Aguilar C (1999) Diversity of arbuscular mycorrhizal fungus populations in heavy metal contaminated soils. Appl Environ Microbiol. 65:718-723

Desaint, S., Arrault, S., Siblot, S., and Fournier, J.C. (2003). Genetic transfer of the mcdgeneinsoil. J. Appl. Microbiol., 95:102-108.

Ding, G., Novak, J.M., Amarasiriwardena, D., Hunt, P.G., and Xing, B. (2002). Soil organic matter characteristics as affected by tillage management. Soil Sci. Soc. Am. J., 66: 421-429.

Doucette, W.J., Bugbee, B.G., Smith, S.C, Pajak, C.J., and Ginn, J.S. (2003). Uptake, metabolism, and phytovolatilization of trichloroethylene by indigenous vegetation: Impact of precipitation. In McCutcheon, S. C. and Schnoor, J. L. Phytoremediation. New York: John Wiley \& Sons Inc., pp. 561588.

Edwards, R., Dixon, D.P., and Walbot, V. (2000). Plant glutathione S-transferases: Enzymes with multiple functions in sickness and in health. Trends Plant Sci., 5: 193-198.

Fenlon, K.A., Jones, K.C., and Semple, K.T. (2007). Development of microbial degradation of cypermethrin and diazinon in organically and conventionally managed soils. $J$. Environ. Monitor., 9:510-515.

Forson, D. D. and Storfer, A. (2006). Atrazine increases ranavirus susceptibility in the tiger salamander, salamander, Ambystoma tigrinum. Ecological Applications, 16: 2325-2332.

Foyer, C.H., and Noctor, G. (2001). The molecular biology and metabolism of glutathione. In Grill, D., Tausz, M., and De Kok, L. (eds.). Significance of glutathione in plant adaptation to the environment. Dordrecht, the Netherlands: Kluwer Academic Publishers, pp. 27-57.

Garmouna, M., Teil, M. J., Blanchard, M., \& Chevreuil, M. (1998). Spatial and temporal variations of herbicide (triazines and phenylureas) concentrations in the catchment basin of the Marne river (France). Science of the Total Environment. 224: 93-107.

Garrison, A.W., Nzengung, V.A., Avants, J.K., Ellington, J.J., Jones, W.J., Rennels, D., and Wolfe, N.L. (2000). Photodegradation of $p, p-D D T$ and the enantiomers of o,p-DDT. Environ. Sci. Technol., 34:1663-1670.

Gavrilescu, M. (2005). Fate of pesticides in the environment and its bioremediation. Engineering in Life Sciences, 5(6): 497526.

Glick, B. (2003). Phytoremediation: Synergistic use of plants and bacteria to clean up the environment. Biotechnology Advances. 21: 383-393.

Glick, B. (2010). Using soil bacteria to facilitate phytoremediation. Biotechnology Advances. 28: 367-374

Gohre V, Paszkowski U (2006) Contribution of the arbuscular mycorrhizal symbiosis to heavy metal phytoremediation. Planta. 223:1115-1122

Gonzalez, M., Miglioranza, K.S., Aizpun de Moreno, J.E., and Moreno, V.J. (2005). Evaluation of conventionally and organically produced vegetables for high lipophilic organochlorine pesticide (OCP) residues. Food Chem Toxicol., 43: 261-269. 
Gonzalez-Chavez C, Harris PJ, Dodd J, Meharg AA (2002) Arbuscular mycorrhizal fungi confer enhanced arsenate resistance on Holcus lanatus. New Phytol. 155:163-171

Gonzalez-Chavez MC, Carrillo-González R, Wright SF and Nichols KA (2004) The role of glo malin, a protein produced by arbuscular mycorrhizal fungi, in sequestering potentially toxic elements. Environ Poll. 130:317-323

Grangeot, M., Chauvel, B., and Gauvrit, C. (2006). Spray retention, foliar uptake and translocation of glufosinate and glyphosate in Ambrosia artemisiifolia. Weed Res., 46:152-162.

Hattab N, Motelica-Heino M, Bourrat X, Mench M (2014) Mobility and phytoavailability of $\mathrm{Cu}, \mathrm{Cr}, \mathrm{Zn}$, and $\mathrm{As}$ in a contaminated soil at a wood preservation site after four years of aided phytostabilization. Environ Sci Pollut Res. 21(17): 10307-10319. doi: 10.1007/s11356-014-2938-0

Hooda PS (2010) Trace elements in soils. Wiley-Blackwell

Hussain, S., Siddique, T., Arshad, M., \& Saleem, M. (2009). Bioremediation and phytoremediation of pesticides: Recent advances. Critical Reviews in Environmental Science and Technology. 39(10):843-907

Inui, H., Shiota, N., Motoi, Y., Ido, Y., Inoue, T., Kodama, T., Ohkawa, Y., and Ohkawa, H. (2001). Metabolism of herbicides and other chemicals in human cytochrome $\mathrm{P} 450$ species and in transgenic potato plants co-expressing human CYP1A1, CYP2B6 and CYP2C19. J. Pestic. Sci., 26: 28-40.

Karpouzas, D.G., Morgan, J.A.W., and Walker, A. (2000). Isolation and characterization of ethoprophos degrading bacteria. FEMS Microbiol. Ecol., 33: 209-218

Kawahigashi, H., Hirose, S., Ohkawa, H., and
Ohkawa, Y. (2003). Transgenic rice plants expressing human CYP1A1 exude herbicide metabolites from their roots. Plant Sci., 165:373-381

Kidd PS, Prieto-Fernandez A, Monterroso C. Rhizosphere microbial community and hexachlorocyclohexane degradative potential in contrasting plant species. Plant Soil. 2008. 302:233-247

Kumpiene, J., Lagerkvist, A. and Maurice, C. 2008. Stabilization of $\mathrm{As}, \mathrm{Cr}, \mathrm{Cu}, \mathrm{Pb}$ and $\mathrm{Zn}$ in soil using amendments--a review. Waste Management (New York, N.Y.), 28(1): 215-225.

Lee, W.Y., Iannucci-Berger, W.A., Eitzer, B.D., White, J.C., and Mattina, M.I. (2003). Plant uptake and translocation of airborne chlordane and comparison with the soil to plant route. Chemosphere, 53:111-121.

Licht, L.A., and Isebrands J.G. (2005). Linking phytoremediated pollutant removal to biomass economic opportunities. Biomass and Bioenergy, 28:203-218

Marmiroli M, Pietrini F, Maestri E, Zacchini M, Marmiroli N, Massacci A (2011) Growth, physiological and molecular traits in Salicaceae trees investigated for phytoremediation of heavy metals and organics. Tree Physiol. 31(12):13191334.

Novakova, M., Mackova, M., Sylvestre, M., and Macek, T. (2007). Preparation of genetically modified plants containing bacterial dioxygenase tool for preferable phytoremediation. J. Biotechnol., 131:S36.

Pascal-lorber, S., and Laurent, F. (2011). Alternative Farming Systems, Biotechnology, Drought Stress and Ecological Fertilisation. Alternative Farming Systems, Biotechnology, Drought Stress and Ecological Fertilisation, 77-105. https://doi.org/10.1007/978-94-007- 


\section{6-1}

Peuke, A.D., and Rennenberg, H. (2005b). Phytoremediation with transgenic trees. Z. Naturforsch., 60:199-207.

Phillips, T. M., Lee, H., Trevors, J. T., \& Seech, A. G. (2006). Full scale in situ bioremediation of hexachlorocyclohexane contaminated soil. Journal of Chemical Technology and Biotechnology, 81:289-298

Qiu, X. H., Zhu, T., Li, J., Pan, H. S., Li, Q. L., Miao, G. F., \& Gong, J. C. (2004). Organ ochlorine pesticides in the air around the Taihu Lake, China. Environmental Science and Technology, 38:1368-1374.

Salt, D.E., Smith, R.D., and Raskin, I. (1998). Phytoremediation. Ann. Rev. Plant Physiol. Plant Mol. Biol., 49:643-668.

Schutzendubel A, Polle A (2002) Plant responses to abiotic stresses: heavy metal-induced oxidative stress and protection by mycorrhization. $J$ Exp Bot. 53:1351-1365

Sharpe, R. (1995). Reproductive biology: Another DDT connection. Nature.375:538-539

Shiota, N., Inui, H., and Ohkawa, H. (1996). Metabolism of the herbicide chlortoluron in transgenic tobacco plants expressing the fused enzyme between rat cytochrome P4501A1 and yeast NADPH-cytochrome P450 oxidoreductase. Pestic. Biochem. Physiol., 54:190-198.

Shiota, N., Nagasawa, A., Sakaki, T., Yabusaki, Y., and Ohkawa, H. (1994). Herbicide resistant tobacco plants expressing the fused enzyme between rat cytochrome P4501A1 (CYP1A1) and yeast NADPH-cytochrome P450 oxidoreductase. Plant Physiol., 106:1723.

Singh, B.K., Walker, A., and Wright, D.J. (2006). Bioremedial potential of fenamiphos and chlorpyrifos degrading isolates: Influence of different environmental conditions. Soil Biol. Biochem., 38:2682-2693.

Sonoki, T., Kajita, S., Ikeda, S., Uesugi, M., Tatsumi, K., Katayama, Y., and Iimura, Y. (2005). Transgenic tobacco expressing fungal laccase promotes the detoxification of environmental pollutants. Appl. Microbiol. Biotechnol., 67: 138-142.

Su, Y.H., Zhu, Y.G., Lin, A.J., and Zhang, X.H. (2005). Interaction between cadmium and atrazine during uptake by rice seedlings (Oryza sativa L.). Chemosphere. 60: 802-809.

Tonin C, Vandenkoornhuyse P, Joner EJ (2001) Assessment of arbuscular mycorrhizal fungi diversity in the rhizosphere of Viola calaminaria and effect of these fungi on heavy metal uptake by clover. Mycorrhiza 10:161168

Trapp, S. (2000). Modeling uptake into roots and subsequent translocation of neutral and ionisable organic compounds. Pest Manage. Sci., 56: 767-778

Turnau K, Miszals Z, Trouvelot A, Bonfante P, Gianinazzi S (1996) Oxalis acetosella as monitoring plant on highly polluted soils. In: Azcon Agiular $C$, Barea JM (eds) Mycorrhizas in integrated system: from genes to plant development. European commission, Luxembourg, pp 483-486

Ultra VU, Tanaka S, Sakurai K, Iwasaki K (2007) Effects of arbuscular mycorrhiza and phosphorus application on arsenic toxicity in sunflower (Helianthus annuus $L$.) and on the transformation of arsenic in the rhizosphere. Plant Soil. 290:29-41

Vacondio, B., Birolli, W. G., Ferreira, I. M., Seleghim, M. H. R., Goncalves, S., Vasconcellos, S. P., \& Porto, A. L. M. (2015). Biodegradation of pentachlorophenol by marine derived 
fungus Trichoderma harziam CBMAI 1677 isolated from ascidian Didemnun ligulum. Biocatalysis and Agricultural Biotechnology. 4(2):266-275.

Vamerali T, Bandiera M, Mosca G (2010) Field crops for phytoremediation of metal contaminated land-A review. Environ Chem Lett. 8:1-17

Wake, H., 2005. Oil refineries: a review of their ecological impacts on the aquatic environment. Estuar. Coast Shelf Sci. 62:131-140. https://doi.org/10.1016/ j.ecss.2004.08.013.

Wang ZH, Zhang JL, Christie P, Li XL (2008) Influence of inoculation with Glomus mosseae or Acaulospora morrowiae on arsenic uptake and translocation by maize. Plant Soil. 311:235-244

Weissenhorn I, Leyval C, Berthelin J (1995a) Bioavailability of heavy metals and arbuscular mycorrhiza in a soil polluted by atmospheric deposition from a smelter. Biol Fertil Soils. 19:22-28

Weissenhorn I, Leyval C, Berthelin J (1995b) Bioavailability of heavy metals and abundance of arbuscular mycorrhiza in a sewage sludge amended sandy soil. Soil Biol Biochem. 27:287-296

Wolfe, N.L., and Hoehamer, C.F. (2003). Enzymes used by plants and microorganisms to detoxify organic compounds. Phytoremediation:

Transformation and control of contaminants. New York: John Wiley \& Sons.

Xia, H., and Ma, X. (2006). Phytoremediation of ethion by water hyacinth (Eichhornia crassipes) from water. Bioresour. Technol., 97: 1050-1054.

Yamada, T., Ishige, T., Shiota, N., Inui, H., Ohkawa, H., and Ohkawa, Y. (2002a). Enhancement of metabolizing herbicides in young tubers of transgenic potato plants with the rat CYP1A1gene. Theo. Appl. Gene., 105:515-520.

Yamada, T., Ohashi, Y., Ohshima, M., Inui, H., Shiota, N., Ohkawa, H., and Ohkawa, Y. (2002b). Inducible cross tolerance to herbicides in transgenic potato plants with the rat CYP1A1gene. Theo. Appl. Gene., 104: 308-314.

\section{How to cite this article:}

Shrirangasami, S. R., S. S. Rakesh' R. Murugaragavan, P. T. Ramesh, S. Varadharaj, R. Elangovan and Saravanakumar, S. 2020. Phytoremediation of Contaminated Soils-A Review. Int.J.Curr.Microbiol.App.Sci. 9(11): 3269-3283. doi: https://doi.org/10.20546/ijcmas.2020.911.392 